\title{
Analisis Sistim Manajemen Dokumentasi Keperawatan pada Poliklinik Gigi Rumah Sakit di Bukittinggi
}

Dewi Rosmalia ${ }^{1}$, Rizanda Machmud², Haryadi Mangkuto ${ }^{3}$

\begin{abstract}
Abstrak
Dokumentasi keperawatan merupakan bukti tertulis pelayanan yang diberikan kepada pasien oleh tenaga keperawatan yang bertujuan untuk menghindari kesalahan, tumpang tindih dan ketidak lengkapan informasi. Dalam asuhan keperawatan agar terbinanya koordinasi yang baik dan dinamis antar tenaga keperawatan serta meningkatkan efisiensi, efektifitas dan menjamin kualitas asuhan keperawatan. Tujuan penelitian ini adalah menganalisis sistim manajemen dokumentasi keperawatan pada poliklinik gigi rumah sakit berdasarkan standar pelayanan keperawatan. Penelitian dilakukan dengan metode analisis kualitatif, sumber data berasal dari observasi, dokumen dan wawancara mendalam. Informan penelitian berjumlah 10 (sepuluh) orang yang terdiri dari direktur rumah sakit, ketua PPGI Kota Bukittinggi, kepala ruangan poliklinik gigi/ kepala instalasi dan perawat gigi di poliklinik gigi rumah sakit di Bukittinggi. Validasi data dilakukan dengan triangulasi, selanjutnya dilakukan analisis data, reduksi data, interpretasi dan komunikasikan makna temuan melalui laporan tertulis. Hasil penelitian didapatkan dokumentasi keperawatan pada poliklinik gigi belum terlaksana dengan optimal, hal ini mempengaruhi proses pendokumentasian, tidak tersedianya kartu khusus pencatatan pemeriksaan dan perawatan gigi juga sangat mempengaruhi sistim dokumentasi keperawatan pada poliklinik gigi. Kesimpulan penelitian ini ialahsistim penyelenggaraan dokumentasi keperawatan pada poliklinik gigi belum terlaksana dengan optimal karena belum tersedianya kartu pencatatan pemeriksaan dan perawatan gigi pada poliklinik gigi rumah sakit, belum adanya SOP dokumentasi keperawatan dan jika ada tidak pernah disosialisasikan.
\end{abstract}

Kata kunci: dokumentasi, poliklinik gigi, manajemen

\begin{abstract}
Nursing documentation is written proof of service to patients by nursing staff that aims to avoid errors, and incompleteness of information overlapping in nursing so good and dynamic coordination between nursing staff and improve the efficiency, effectiveness and ensure the quality of nursing care. The objective of this study was to analyze nursing documentation management system in a hospital dental clinic based nursing care standards. The study was conducted with qualitative analysis methods, data sources derived from observations, documents and in-depth interviews. Informants numbered 10 (ten ) members consisting of the hospital director, chief dental nurses union Indonesia ( PPGI ) of Bukittinggi, the head of the room / installation and head nurse at the dental clinic dental hospital in Bukittinggi. Data validation is done by triangulation, then performed the data analysis, data reduction, data display and conclusion. The results showed nursing documentation in the dental clinic has not done optimally, this affects the process of documenting, recording card unavailability of dental examinations and treatment also greatly affect the nursing documentation system in the dental clinic. In conclusion, the implementation of a nursing documentation system at a dental clinic is not performing optimally due to the unavailability of recording card dental examinations and treatment at the hospital dental clinic, lack of standard operating procedures (SOP) nursing documentation.
\end{abstract}

Keywords: documentation, dental clinic, management 
Affiliasi penulis: 1. Program Studi S2 Kesehatan Masyarakat UNAND (Universitas Andalas Padang), 2. IImu Kesehatan Masyarakat Fakultas Kedokteran UNAND, 3. Gigi dan Mulut RSUP DR M. Jamil Padang.

Korespondensi: Dewi Rosmalia, E-mail:dewirosmalia2@yahoo.com. Telp: 085263756191

\section{PENDAHULUAN}

Undang-Undang RI Nomor 44 Tahun 2009 tentang Rumah Sakit Pasal 52 menyatakan bahwa setiap rumah sakit wajib melakukan pencatatan dan pelaporan semua penyelenggaraan kegiatan rumah sakit dalam bentuk sistim informasi manajemen berupa pencatatan, penyimpanan, pelaporan dan pemusnahan dalam waktu tertentu sesuai peraturan perundang-undangan. ${ }^{1}$

Rumah sakit dalam pengelolaannya mempunyai pilar yang saling terkait satu sama lain yaitu: administrasi, manajemen berupa perencanaan setiap kegiatan, disiplin dari pelakunya, leadership dan kepemimpinan diri. Teori menyatakan "tulis apa yang ingin dilakukan, lakukan apa yang telah ditulis dan tulis apa yang telah dilakukan". Pelayanan yang diselenggarakan rumah sakit ada dua jenis yaitu pelayanan kesehatan dan administratif. Salah satu bentuk pelayanan kesehatan adalah pelayanan di poliklinik gigi berupa promotif, preventif, kuratif, rehabilitatif. Pelayanan administratif salah satunya adalah dokumentasi keperawatan yang berisi catatan keperawatan sebagai bukti pelaksanaan proses keperawatan dan catatan tanggapan/respon klien terhadap tindakan medis dan tindakan keperawatan yang telah dilaksanakan. ${ }^{2}$

Bagian integral manajemen rumah sakit berperan penting dalam meningkatkan mutu pelayanan berupa aspek administratif, hukum, keuangan, riset, edukasi serta dokumentasi. Kegiatan dokumentasi berupa menghimpun, mengolah, menganalisis dan menyimpan yang dijadikan sebagai informasi yang cukup penting dan diperlukan dalam membuat rencana program kerja untuk perkembangan organisasi. Dokumen digunakan sebagai bukti tertulis yang memiliki nilai hukum dan disimpan dalam waktu tertentu sebagai sumber keterangan, penyelidikan ilmiah, alat bantu bukti keabsahan suatu kegiatan. ${ }^{3}$

Keberhasilan jaminan mutu rumah sakit salah satu kuncinya adalah pemanfaatan data, dokumentasi kualitatif dan kuantitatif sebagai petunjuk dalam pengambilan keputusan secara internal oleh profesi kesehatan dalam organisasi rumah sakit. ${ }^{4}$

Profesi pemberi pelayanan kesehatan pada poliklinik gigi diantaranya perawat gigi yang merupakan bagian dari tenaga keperawatan. Perawat gigi adalah setiap orang yang telah lulus pendidikan perawat gigi ditandai dengan kemampuan yang didukung pengetahuan teoritis keperawatan gigi, terdidik dan terlatih sesuai ketentuan perundangundangan dan berwenang menyelenggarakan pekerjaan keperawatan gigi sesuai bidang keahlian. Salah satu kompetensi keahlian perawat gigi adalah dokumentasi keperawatan dengan kompetensi dasar mengidentifikasi kelengkapan dan melaporkan dokumentasi keperawatan. ${ }^{5}$

Penyelenggaraan proses keperawatan terdiri dari pengkajian, diagnosa, perencanaan, implementasi dan evaluasi. Semua tindakan tersebut harus didokumentasikan sebagai bukti penyelenggaraan proses keperawatan. Data klinis yang lengkap dan berkualitas dapat meningkatkan mutu layanan kesehatan. Keengganan klinisi menulis secara lengkap setiap proses penatalaksanaan medis merupakan kendala yang dihadapi. ${ }^{2}$

Dokumentasi keperawatan terdiri dari 1) keterampilan berkomunikasi untuk pengumpulan data dan menciptakan hubungan baik antara perawat dan klien dalam pemecahan masalah klien. 2) dokumentasi proses keperawatan yang merupakan metode pemecahan masalah secara sistimatis sesuai kaidah keperawatan dan 3) standar dokumentasi dapat memberi informasi pernyataan kualitas dan kuantitas dokumentasi untuk memperkuat pola pendokumentasian keperawatan. ${ }^{7}$

Observasi awal didapatkan bahwa dokumentasi proses keperawatan tidak diisi lengkap, hanya tercantum tanggal, diagnosis dan pelaksanaan tindakan. Berdasarkan wawancara pengisian dokumentasi keperawatan gigi dilaksanakan sesuai kebiasaan, jika ada tugas limpah dari dokter gigi tidak ada dokumentasi tertulis dan tidak tersedia status khusus gigi dan mulut.

Mengingat pentingnya pelaksanaan dokumentasi keperawatan dalam bentuk sistim informasi manajemen berupa pencatatan, seharusnya 
permasalahan penyelenggaraan dokumentasi dapat diatasi karena standar dokumentasi keperawatan sudah ada, sehingga perlu upaya manajemen dalam mengatasi penyelenggaraan dokumentasi agar dokumentasi keperawatan gigi sesuai dengan standar dokumentasi keperawatan.

Berdasarkan hal diatas dapat dibuat rumusan masalah bagaimana sistim penyelenggaraan, apa permasalahan penyelenggaraan dan apa upaya manajemen untuk mengatasi permasalahan penyelenggaraan dokumentasi keperawatan pada poliklinik gigi di rumah sakit? Tujuan penelitian adalah menganalisis sistim manajemen dokumentasi keperawatan pada poliklinik gigi rumah sakit berdasarkan standar pelayanan keperawatan.

\section{METODE}

Rancangan penelitian menggunakan metode kualitatif, penelitian dilaksanakan dari Februari sampai Maret 2014 pada poliklinik gigi rumah sakit di Bukittinggi.

Informan penelitian ditentukan berdasarkan teknik purposive sampling melalui pertimbangan, kesesuaian dan kecukupan berdasarkan tanggung jawab yang terdiri dari direktur rumah sakit, ketua Persatuan Perawat Gigi Indonesia (PPGI) Kota Bukittinggi, kepala poliklinik gigi serta perawat gigi di poliklinik gigi rumah sakit,

Pengumpulan data dimulai dari dokumen, observasi dan wawancara. validasi data dengan triangulasi yang meliputi: Triangulasi sumber, triangulasi metode dan triangulasi data yang akan meningkatkan kualitas laporan penelitian. Analisis data berkaitan dengan reduksi data, interpretasi dan komunikasikan temuan melalui laporan tertulis.
Manajemen merupakan proses yang terdiri dari perencanaan, pengorganisasian, pengarahan dan pengendalian untuk mencapai tujuan. ${ }^{8}$

Dokumentasi merupakan bagian dari administrasi sebagai jaminan pelayanan yang diberikan kepada pasien dan dapat mendukung kualitas pelayanan yang diberikan. Pelaksanaan manajemen dokumentasi keperawatan sebagai kegiatan manajerial perawat gigi yang terdiri dari input, proses dan output. Dalam mengelola dokumen di klinik gigi sehingga dokumen tertata rapi dan mudah di akses sesuai aturan, data yang didapat diolah untuk memperoleh informasi.

\section{Input}

\section{Sumber daya manusia (SDM)}

Jumlah perawat gigi sudah mencukupi bahkan berlebih dibandingkan dengan beban kerja, luas lokasi kerja serta jumlah peralatan yang tersedia, tetapi pelaksanaan dokumentasi proses keperawatan tidak berjalan sesuai konsep dokumentasi keperawatan walaupun perawat gigi telah berada satu bagian dengan keperawatan

Pelaksaaan pekerjaan hanya satu poliklinik gigi rumah sakit yang mempunyai uraian tugas (Job description) untuk perawat gigi yang dibuat berdasarkan latar belakang pendidikan, sehingga perawat gigi bekerja sesuai dengan uraian tugas yang ada. Rumah sakit yang tidak memiliki uraian tugas dalam melaksanakan pekerjaan sehingga perawat gigi bekerja bisa melebihi kompetensi dan bahkan bisa kurang dari kompetensi yang seharusnya. Pelaksanaan pekerjaan yang melebihi kompetensi tidak terdapat surat tugas limpah wewenang tertulis. Masalah SDM poliklinik gigi dapat dilihat pada Tabel 1.

\section{HASIL DAN PEMBAHASAN}

Tabel 1. SDM penyelenggaraan dokumentasi keperawatan pada poliklinik gigi rumah sakit

\begin{tabular}{|c|c|c|c|}
\hline Teori & Masalah & Penyebab & Solusi \\
\hline $\begin{array}{l}\text { Perencanaan SDM yang baik } \\
\text { dalam sistim manajemen } \\
\text { terdiri dari skill inventory, job } \\
\text { analysis dan replacement } \\
\text { chart SDM bekerja sesuai } \\
\text { standar kompetensi }\end{array}$ & $\begin{array}{l}\text { Tidak tersedianya uraian tugas } \\
\text { Tidak tersedianya diagram } \\
\text { jabatan dan SDM yang ada } \\
\text { bekerja tidak sesuai } \\
\text { kompetensi }\end{array}$ & $\begin{array}{l}\text { Perawat gigi bekerja } \\
\text { sesuai tugas dan tradisi } \\
\text { yang ada serta tidak } \\
\text { pernah ada permasalahan }\end{array}$ & $\begin{array}{l}\text { Bekerja harus sesuai } \\
\text { kompetensi, tersedianya } \\
\text { uraian tugas tertulis dan } \\
\text { Penanggung jawab kegiatan }\end{array}$ \\
\hline
\end{tabular}




\section{Sarana dan prasarana}

Kelengkapan sarana pelayanan pasien dapat terpenuhi, sarana administrasi poliklinik berupa status khusus keperawatan gigi tidak terpenuhi, sementara pihak manajemen akan memenuhi permintaan administrasi yang diajukan asalkan tidak melanggar aturan dan memenuhi standar kebutuhan. Pembahasan sarana administrasi poliklinik gigi dapat dilihat pada Tabel 2 dibawah

Tabel 2. Sarana administrasi poliklinik gigi dalam penyelenggaraan dokumentasi keperawatan

\begin{tabular}{|c|c|c|c|}
\hline Teori & Masalah & Penyebab & Solusi \\
\hline $\begin{array}{l}\text { Sarana administrasi poliklinik gigi } \\
\text { adalah buku register pasien, kartu } \\
\text { status asuhan keperawatan gigi dan } \\
\text { mulut, kartu pendaftaran pasien, surat } \\
\text { rujukan, kwitansi, stempel dan map. } \\
\text { Sarana utama sistim pencatatan } \\
\text { adalah ketersediaan format/ formulir } \\
\text { pasien poliklinik yang sesuai } \\
\text { kebutuhan, }\end{array}$ & $\begin{array}{l}\text { Tidak tersedianya kartu } \\
\text { khusus keperawatan gi- } \\
\text { gi pada poliklinik gigi }\end{array}$ & $\begin{array}{l}\text { Belum ada perawat gigi } \\
\text { yang mengajukan permin- } \\
\text { taan status khusus kepe- } \\
\text { rawatan gigi karena } \\
\text { belum ada pedoman } \\
\text { untuk pengajuannya }\end{array}$ & $\begin{array}{l}\text { Penyediaan kartu penca- } \\
\text { tatan pemeriksaan dan } \\
\text { perawa tan gigi }\end{array}$ \\
\hline
\end{tabular}

\section{Kebijakan dan SOP (Standar Operasional Prosedur)}

Hanya satu poliklinik gigi rumah sakit yang memiliki SOP dokumentasi keperawatan, yang penting dapat melayani kebutuhan klien dan bekerja sesuai prosedur. Adanya SOP dari pihak manajemen rumah sakit seharusnya digunakan sebagai pedoman untuk pendokumentasian keperawatan, tetapi yang terlaksana tetap menggunakan kebiasaan lama dengan hanya mencantumkan gigi dan kasus yang ditindak karena SOP hanya disimpan tanpa disosialisasikan dan pihak manajemen tidak mengevaluasi pelaksanaan SOP yang ada, hal ini dapat dilihat pada tabel 3 dibawah

Tabel 3. SOP dokumentasi keperawatan pada poliklinik gigi

\begin{tabular}{|c|c|c|c|}
\hline Teori & Masalah & Penyebab & Solusi \\
\hline $\begin{array}{l}\text { SOP adalah pedoman untuk } \\
\text { memastikan bahwa tindakan } \\
\text { dilaksanakan secara efektif, } \\
\text { konsisten, standar dan sistimatis. } \\
\text { Pendokumentasian keperawatan } \\
\text { pada poliklinik gigi adalah } \\
\text { kebijakan direktur rumah sakit } \\
\text { secara tertulis yang mengatur } \\
\text { penyelenggaraan dokumentasi } \\
\text { keperawatan. }\end{array}$ & $\begin{array}{l}\text { Hanya satu poliklinik gigi } \\
\text { rumah sakit yang memiliki } \\
\text { SOP pada poliklinik gigi, } \\
\text { tetapi SOP yang ada hanya } \\
\text { disimpan sebagai arsip dan } \\
\text { tidak dipublikasikan }\end{array}$ & $\begin{array}{l}\text { Rumah sakit lain karena } \\
\text { rumah sakit khusus } \\
\text { sehingga poliklinik gigi } \\
\text { dianggap sebagai bagian } \\
\text { kecil yang tidak mendapat } \\
\text { perhatian. Satu rumah sakit } \\
\text { lain yang penting dapat } \\
\text { melayani kebutuhan klien } \\
\text { dan bekerja sesuai prosedur }\end{array}$ & $\begin{array}{l}\text { Membuat SOP dokume- } \\
\text { tasi keperawatan untuk } \\
\text { pedoman kerja dan } \\
\text { diharapkan mengontrol } \\
\text { dan evaluasi berkelan- } \\
\text { jutan dari SOP yang ada }\end{array}$ \\
\hline
\end{tabular}

\section{Pengembangan staf}

Kebijakan dan pengembangan staf poliklinik gigi tidak sama pada setiap rumah sakit. pada satu rumah sakit pihak manajemen mendukung untuk pengembangan staf, tetapi tidak meninggalkan tugas pokok, pada rumah sakit lain pengembangan staf terbatas karena profesi perawat gigi bersifat spesifik, selain itu karena perawat gigi masih tenaga sukarela maka untuk pengembangan berdasarkan pengabdian, tapi tidak dibatasi jika ada pekerjaan yang lebih baik, hal ini dapat dilihat pada Tabel 4. 
Tabel 4. Pengembangan staf perawat gigi poliklinik

\begin{tabular}{|c|c|c|c|}
\hline Teori & Masalah & Penyebab & Solusi \\
\hline $\begin{array}{l}\text { Setiap staf mempunyai kesempatan } \\
\text { yang sama mengikuti pendidikan } \\
\text { berkelanjutan untuk meningkatkan } \\
\text { pengetahuan dan keterampilan melalui } \\
\text { bimbingan, pendidikan tambahan, } \\
\text { kursus, seminar dan pendidikan formal } \\
\text { di kampus }\end{array}$ & $\begin{array}{l}\text { Pengembangan staf perawat gigi } \\
\text { rumah sakit boleh melalui } \\
\text { pendidikan formal tetapi tidak } \\
\text { meninggalkan tugas pokok dan } \\
\text { perawat gigi tidak pernah } \\
\text { mendapat pelatihan pelayanan } \\
\text { dan administrasi }\end{array}$ & $\begin{array}{l}\text { Kompetensi perawat } \\
\text { gigi bersifat spesifik }\end{array}$ & $\begin{array}{l}\text { Memberikan pelatihan } \\
\text { untuk pelayanan dan } \\
\text { administrasi pendoku- } \\
\text { mentasian }\end{array}$ \\
\hline
\end{tabular}

\section{Proses keperawatan}

Proses keperawatan belum berjalan sesuai prosedur keperawatan karena tidak dilakukan pengkajian awal, catatan perkembangan serta data terbaru klien, tidak ada rencana keperawatan dan evaluasi keperawatan. Yang terdokumentasi hanya

Tabel 5. Pengkajian keperawatan pada poliklinik gigi

\begin{tabular}{|c|c|c|c|}
\hline Teori & Masalah & Penyebab & Solusi \\
\hline $\begin{array}{l}\text { Pengkajian adalah tahap awal proses } \\
\text { keperawatan berupa pengumpulan data } \\
\text { yang sistimatis dalam asuhan } \\
\text { keperawatan sesuai kebutuhan klien, } \\
\text { diperoleh dari wawancara (anamnesis), } \\
\text { pemeriksaan fisik, pengamatan } \\
\text { (observasi) dan rekam medis }\end{array}$ & $\begin{array}{l}\text { Perawat gigi tidak selalu } \\
\text { melakukan pengkajian, jika } \\
\text { melakukan pengkajian tidak } \\
\text { didokumentasikan dengan } \\
\text { lengkap }\end{array}$ & $\begin{array}{l}\text { Sudah menjadi kebia- } \\
\text { saan dan posisi } \\
\text { perawat gigi sebagai } \\
\text { asistensi dokter gigi }\end{array}$ & $\begin{array}{l}\text { Mendokumentasikan } \\
\text { pengkajian sebagai } \\
\text { kompetensi perawat gigi }\end{array}$ \\
\hline
\end{tabular}

\section{Diagnosis keperawatan}

Tabel 6. Diagnosis keperawatan pada poliklinik gigi

\begin{tabular}{lrrrrrrr}
\hline & \multicolumn{2}{c}{ Teori } & & Masalah & Penyebab & Solusi \\
\hline Diagnosis & keperawatan & merupakan & Perawat gigi tidak mela- & Diagnosis ditegak- & Mendokumentasikan & diag- \\
proses & mengidentifikasi & masalah & kukan & diagnosis kepera- & kan oleh dokter gigi & nosis keperawatan sebagai \\
kesehatan & pasien sebagai suatu & watan & & kompetensi perawat gigi \\
pernyataan & singkat, tegas dan jelas & & & & \\
yang didasarkan pada pengumpulan dan & & & & & \\
evaluasi data
\end{tabular}

\section{KESIMPULAN}

Poliklinik gigi melakukan kegiatan mulai dari pengkajian, diagnosis, rencana intervensi, intervensi keperawatan dan evaluasi proses keperawatan. Untuk menjamin keamanan petugas dan keselamatan klien, maka seharusnya setiap tahapan dari proses yang dilaksanakan didokumentasikan dengan lengkap, sehingga "apa yang direncanakan dilaksanakan, apa yang di tulis dikerjakan dan apa yang dikerjakan diagnosis dan intervensi gigi bersangkutan karena sudah menjadi kebiasaan dan tidak pernah dipermasalahkan, yang terpenting dapat melayani kebutuhan dan keluhan klien 


\section{DAFTAR PUSTAKA}

1. Depkes RI. Undang-undang kesehatan no 36 tahun 2009. Jakarta: Sinar Grafika; 2009.

2. Suarli S. Manajemen keperawatan dengan pendekatan praktis. Jakarta: EMS; 2009.

3. Sutrisno. Fungsi dokumentasi asuhan keperawatan dalam melindungi profesi perawat (tesis). Semarang: Program Pascasarjana Unika Soegijapranata; 2007.

4. Pohan I. Jaminan mutu layanan kesehatan. Jakarta, EGC, 2006.
5. Depkes RI. Peraturan menteri kesehatan RI nomor 58 , tentang penyelenggaraan pekerjaan perawat gigi. 2012.

6. Nursalam. Proses dokumentasi keperawatan, Jakarta: Salemba Medika; 2008.

7. Aditama YA. Manajemn administrasi rumah sakit. Edisi ke-2. Jakarta: UIP; 2007.

8. Hasibuan M. Manajemen dasar, pengertian dan Masalah. Edisi revisi. Jakarta: Bumi Aksara; 2011. 